\title{
MAURICE DE GUÉRIN, Lettres à Barbey d'Aurevilly
}

\section{Lise Sabourin}

\section{CpenEdition \\ Journals}

Édition électronique

URL : https://journals.openedition.org/studifrancesi/22976

DOI : 10.4000/studifrancesi.22976

ISSN : 2421-5856

\section{Éditeur}

Rosenberg \& Sellier

\section{Édition imprimée}

Date de publication : 1 avril 2020

Pagination : 199-200

ISSN : 0039-2944

\section{Référence électronique}

Lise Sabourin, « MAURICE DE GUÉRIN, Lettres à Barbey d'Aurevilly», Studi Francesi [En ligne], 190 (LXIV | I) | 2020, mis en ligne le 01 mai 2020, consulté le 03 août 2021. URL : http://journals.openedition.org/ studifrancesi/22976; DOI : https://doi.org/10.4000/studifrancesi.22976

Ce document a été généré automatiquement le 3 août 2021.

\section{(c) (†)}

Studi Francesi è distribuita con Licenza Creative Commons Attribuzione - Non commerciale - Non opere derivate 4.0 Internazionale. 


\title{
MAURICE DE GUÉRIN, Lettres à Barbey d'Aurevilly
}

\author{
Lise Sabourin
}

\section{RÉFÉRENCE}

MAURICE DE GUÉRIN, Lettres à Barbey d'Aurevilly, préface de J. Barbey d'Aurevilly, établissement des textes, postface, notes et bibliographie par A. Burin et P. Noir, Paris, L'Harmattan, 2019, «Les Introuvables», 76 pp.

1 Malgré l'article de Sand en 1840 dans la "Revue des deux mondes", Maurice de Guérin, on le sait, faillit demeurer un écrivain méconnu, si son camarade du collège Stanislas, Barbey d'Aurevilly, n'avait entretenu la flamme en faisant publier ses œuvres et en préfaçant les lettres qu'il avait reçues de lui en 1836, 1838 et 1839 jusqu'à ses derniers instants. Sainte-Beuve avait bien introduit, à sa demande déjà, les Reliquiae en 1861, mais d'une plume trop "voilée» pour atteindre vraiment à cet «André Chénier du panthéisme» que Barbey considère comme le «poète du mystérieux et de l'immense».

2 La collection des «Introuvables» chez L'Harmattan nous restitue l'édition princeps en 1908 de ces missives avec leur préface par Barbey et, en appendice, des fragments écrits par Jules Levallois parus dans "L'Opinion" en février-mars 1861 et une lettre de Barbey de juin 1861. Alexandre Burin et Pascal Noir, outre leurs notes et la bibliographie, ont écrit une postface (pp. 57-70) précisant les circonstances et les liens tissés entre amis, y compris Levallois et Trébutien, secrétaires respectifs de Sainte-Beuve et Barbey, autour de l'auteur du Centaure, ce frère de Goethe, disciple de Lamennais dans sa tentative de concilier libéralisme politique et catholicisme romain, mais aussi concepteur des memoranda associés à la création et prosateur paysagiste digne de Sand et Chateaubriand. 